ReVISTA de BIOLOGía TROPICAL

\title{
Leaf morphological strategies of seedlings and saplings of Rhizophora mangle (Rhizophoraceae), Laguncularia racemosa (Combretaceae) and Avicennia schaueriana (Acanthaceae) from Southern Brazil
}

\author{
Andressa Pelozo ${ }^{1}$, Maria Regina T. Boeger ${ }^{2}$, Carolina Sereneski-de-Lima ${ }^{3} \&$ Patricia Soffiatti $^{4 *}$ \\ 1. Universidade Federal do Paraná, Programa de Pós-Graduação em Botânica, Departamento de Botânica, SCB, Centro \\ Politécnico, Caixa Postal 19031, Curitiba, PR. Brazil, CEP 81.531-880; pelozo.andressab@gmail.com \\ 2. Programa de Pós-Graduação em Ecologia, SCB, Centro Politécnico, Caixa Postal 19031, Curitiba, PR, Brazil, CEP \\ 81.531-880; mrtboeger@gmail.com \\ 3. Programa de Pós-Graduação em Ecologia, SCB, Centro Politécnico, Caixa Postal 19031, Curitiba, PR, Brazil, CEP \\ 81.531-880; sereneskilima@gmail.com \\ 4. Universidade Federal do Paraná, Departamento de Botânica, SCB, Centro Politécnico, Caixa Postal 19031, Curitiba, \\ PR. Brazil, CEP 81.531-880; psoffiatti.ufpr@gmail.com \\ * Correspondence
}

\section{Received 26-I-2015. Corrected 27-VII-2015. Accepted 25-VIII-2015.}

\begin{abstract}
The initial phase of a plant life cycle is a short and critical period, when individuals are more vulnerable to environmental factors. The morphological and anatomical study of seedlings and saplings leaf type enables the understanding of species strategies of fundamental importance in their establishment and survival. The objective of this study was to analyze the structure of seedlings and saplings leaf types of three mangrove species, Avicennia schaueriana, Laguncularia racemosa, Rhizophora mangle, to understand their early life adaptive strategies to the environment. A total of 30 fully expanded cotyledons (A. schaueriana and L. racemosa), 30 leaves of seedlings, and 30 leaves of saplings of each species were collected from a mangrove area in Guaratuba Bay, Paraná State, Brazil. Following standard methods, samples were prepared for morphological (leaf dry mass, density, thickness) and anatomical analysis (epidermis and sub-epidermal layers, stomata types, density of salt secretion glands, palisade and spongy parenchyma thickness). To compare leaf types among species one-way ANOVA and Principal Component Analysis were used, while Cluster Analysis evaluated differences between the species. We observed significant structural differences among species leaf types. A. schaueriana showed the thickest cotyledons, while $L$. racemosa presented a dorsiventral structure. Higher values of the specific leaf area were observed for seedlings leaves of $A$. schaueriana, cotyledons of $L$. racemosa and saplings leaves of $A$. schaueriana and $R$. mangle. Leaf density was similar to cotyledons and seedlings leaves in $A$. schaueriana and $L$. racemosa, while $R$. mangle had seedlings leaves denser than saplings. A. schaueriana and $R$. mangle showed hypostomatic leaves, while $L$. racemosa amphistomatic; besides, A. chaneriana showed diacytic stomata, while $L$. racemosa anomocytic, and $R$. mangle ciclocytic. Seedling leaves were thicker in $R$. mangle $(535 \mu \mathrm{m})$ and L. racemosa $(520 \mu \mathrm{m})$ than in A. schaueriana $(470.3 \mu \mathrm{m})$; while saplings leaves were thicker in L. racemosa $(568.3 \mu \mathrm{m})$ than in $A$. schaueriana seedlings $(512.4 \mu \mathrm{m})$ and $R$. mangle $(514.6 \mu \mathrm{m})$. Besides, seedlings leaves palisade parenchyma showed increasing thickness in L. racemosa $(119.2 \mu \mathrm{m})<$ A. schaueriana $(155.5 \mu \mathrm{m})<$ $R$. mangle $(175.4 \mu \mathrm{m})$; while in saplings leaves as follows $R$. mangle $(128.4 \mu \mathrm{m})<$ A. schaueriana $(183.4 \mu \mathrm{m})$ $<$ L. racemosa $(193.9 \mu \mathrm{m})$. Similarly, seedlings leaves spongy parenchyma thickness values were as follows $A$. schaueriana $(182.6 \mu \mathrm{m})=R$. mangle $(192.8 \mu \mathrm{m})<$ L. racemosa $(354.4 \mu \mathrm{m})$; while in saplings were $A$. schaueriana $(182.6 \mu \mathrm{m})=R$. mangle $(187.3 \mu \mathrm{m})<L$. racemosa $(331.3 \mu \mathrm{m})$. The analyzed traits, in different combinations, represent morphological adjustments of leaf types to reduce water loss, eliminate salt excess, increase the absorption of light, allowing a higher efficiency on the maintenance of physiological processes in this initial growth stage. Rev. Biol. Trop. 64 (1): 305-317. Epub 2016 March 01.
\end{abstract}

Key words: adaptive strategies, cotyledons, functional morphology, morphological adaptations, salt glands. 
Mangroves are transitional coastal ecosystems occurring between terrestrial and marine environments typical of tropical and subtropical regions. They are highly dynamic, marked by periodical floods, salt variations, oxygen shortage and unstable soils (Paraguassu \& Silva, 2007; Schaeffer-Novelli, Cintrón-Molero, Soares, \& De-Rosa, 2000).

The mangrove flora is composed of halophytes (Silva, Martins, \& Cavalheiro, 2010), salt tolerant species that develop several adaptations to cope with such habitat like salt exclusion mechanism by ultra-filtration in root cells, salt glands, accumulation of ions in leaf cells, leaf succulence and the presence of osmoprotectors (Patel, Gupta, \& Pandey, 2010). Besides, some species have a specialized root system presenting pneumatophores and rizophores, which guarantee the oxygen supply in an anoxic condition.

The species diversity is extremely low in mangroves (Kathiresan, 2008). In Brazil only three families are found comprising four genera and seven species (Schaeffer-Novelli, Cintrón-Molero, \& Adaime, 1990). In Southern Brazil only three species occur: Avicennia schaueriana Stapf and Leachm. ex Moldenke (Acanthaceae), Laguncularia racemosa (L.) Gaertn. (Combretaceae) and Rhizophora mangle L. (Rhizophoraceae).

Seedlings and saplings establishment is one of the most important steps in forest regeneration (Grubb, 1977). This process in mangroves is directly affected by physiological constraints caused by salinity and flooding (Cardona-Olarte, Twilley, Krausse, \& RiveraMonroy, 2006). The anatomical study of early stages of plant development permits the recognition of structural adaptations allowing the understanding of functional aspects regarding species adaptations during their establishment (Ressel, Guilherme, Schiavini, \& Oliveira, 2004; Souza, 2003; Vogel, 1980).

In this context, this study aims to: 1 . Compare the structure of leaves of mangrove species seedlings and saplings. 2. Identify which morphological and anatomical traits vary among leaf types of the same species and which characteristics vary among the species within the same developmental stage. 3 . Which features can be considered adaptive to mangrove conditions in the early stages of species development?

\section{MATERIALS AND METHODS}

Study area: This study was conducted in Guaratuba Bay, Paraná state, Brazil (2550'00” S - 48 $34^{\prime} 52^{\prime}$ W), the second largest estuary system on Parana state coast, with $51 \mathrm{~km}^{2}$ (Noernberg, Angelotti, Caldeira, \& Ribeiro de Sousa, 2008). The climate is classified as Cfa type, according to Köppen (1948) (subtropical mesothermic, with hot summers, without dry season). The average temperature is 20.8 ${ }^{\circ} \mathrm{C}$, with $18.0{ }^{\circ} \mathrm{C}$ and $24.2{ }^{\circ} \mathrm{C}$ minimum and maximum values, respectively. The annual precipitation is $719.8 \mathrm{~mm}$ (Instituto Tecnológico Simepar, for 2010 and 2011, http://www.simepar.br/). The soil type is Histosol thiomorphic sapric salic/sodic (Embrapa, 1999). Measurements of salinity of the interstitial water varied from 22.2 to $27.6 \%$ and the potential redox varied from -308.2 to $-323.8 \mathrm{mV}$.

Species measurements and anatomy: Seedlings and saplings leaves of the occurring tree species Avicennia schaueriana, Laguncularia racemosa and Rhizophora mangle were studied. Plant individuals considered seedlings were those with the first pair of leaves fully expanded (Souza, 2003). Individuals from this stage on until up to one meter of height (Cintrón \& Schaeffer-Novelli, 1984) were classified as saplings. The study was based on the anatomy of cotyledons, fully expanded leaves of seedlings and saplings of all species. For $R$. mangle seedlings, the cotyledon analysis was not performed because the seedlings remain attached to the mother plant (viviparity), and they are not under the same abiotic conditions as the other species.

In total, 60 cotyledons, 90 seedlings leaves and 90 saplings leaves were collected: 30 fully expanded cotyledons; 30 leaves of seedlings and 30 leaves of saplings of each species. The 
individuals were in the understory, in an inland area within the mangrove. The leaves of seedlings and saplings were collected between the 2nd and 5th nodes from the apex. All leaves were dehydrated in forced ventilation oven at $50^{\circ} \mathrm{C}$ until obtaining constant mass, for area and dry mass calculations. Area $\left(\mathrm{cm}^{2}\right)$ was measured from images obtained with a flatbed scanner calibrated with Sigma Scan PRO software (version 5.0. SPSS Inc., Chicago, IL. USA). Dry mass (g) was estimated with a digital analytical balance. The specific leaf area (SLA, $\mathrm{cm}^{2} / \mathrm{g}$ ) was estimated by the ratio of leaf area $\left(\mathrm{cm}^{2}\right) /$ leaf dry mass $(\mathrm{g})$ (Witkowski \& Lamont, 1991). The total thickness of leaves was obtained with a digital caliper in fresh leaf types. For density, the following formula was used: density $=$ leaf dry mass/leaf area $\mathrm{x} 1 /$ thickness $\left(\mathrm{mm}^{3} / \mathrm{mg}\right)$.

For each species, 30 samples from the median region of each leaf were selected for anatomical measurements. Samples were fixed in FAA 70, conserved in ethanol $70 \%$ (Johansen, 1940), and hand sectioned transversally, clarified with sodium hypochlorite $10 \%$, stained with Toluidine Blue $1 \%$ and mounted in glycerin. In transverse sections, epidermis adaxial and abaxial surfaces, sub-epidermal layers, palisade and spongy parenchyma thickness and total thickness were measured, and the ratio palisade/spongy parenchyma calculated. All measurements were made in an Olympus CBB light microscope, with a micrometric ocular.

The median region of two previously fixed samples of each type of leaf, of each species, was embedded in synthetic resin (Leica $\left.{ }^{\circledR}\right)$. Cross sections, $7 \mu \mathrm{m}$ thick, were obtained in rotatory microtome and stained with aqueous Toluidine Blue $0.05 \%$, mounted with Entelan ${ }^{\circledR}$. The photographic register was made in the light microscope Olympus BX51, coupled with digital camera Canon Power Shot F50.

Stomata types were identified from the dissociated epidermis taken from the median region of each leaf type, using acetic acid and hydrogen peroxide (Franklin, 1945). The dissociated samples were stained with Safranin
$1 \%$ and mounted as temporary slides. The density of salt secretion glands $\left(\mathrm{mm}^{2}\right)$ was measured using clear nail polish imprints from the median region of leaf epidermal surface, in 30 leaves per species using a bright-field microscopy, projected in a $1 \mathrm{~mm}^{2}$ square.

We used scanning electron microscopy to detail leaves anatomy; for this, the entire leaves were dehydrated in ascendant alcohol series and $\mathrm{CO}_{2}$ critical-point-dried (Bal-Tec CPD030), adhered to stubs and sputter coated with gold (Balzers Union FL9496 SCD-030). The images were obtained in a Scanning Electron Microscope JEOL JSM-6360LV.

The interspecific comparison of leaf types among species was performed using a one-way ANOVA. Means were compared by Fisher's test, with $5 \%$ of significance, using the software Statistica version 7.0 (STATISTICA, version 70). A Principal Component Analysis and a Cluster Analysis were carried out to evaluate differences between the species.

\section{RESULTS}

Cotyledons: In cross section, the cotyledons showed a uniseriate epidermis in Avicennia schaueriana (Fig. 1A, Fig. 1B and Fig. 1C) and Laguncularia racemosa (Fig. 1D), composed of rounded cells and convex external periclinal walls in the former, and straight external periclinal walls in the latter, covered by a thin cuticle. The blade was amphistomatic and stomata in surface view are diacytic in $A$. schaueriana and anomocytic in L. racemosa. In A. schaueriana, salt glands are scattered among ordinary epidermal cells and located in small depressions in both surfaces (Fig. 1A), composed of a collector, neck and head cells, covered with a thin cuticle. The mesophyll was homogeneous in A. schaueriana, formed by approximately 60 layers of regular parenchyma cells (Fig. 1A, Fig. 1B and Fig. 1C). Small collateral vascular bundles are scattered in the mesophyll. In L. racemosa, mesophyll was dorsiventral, composed of two to three layers of rectangular chlorophyll cells, adjacent to 

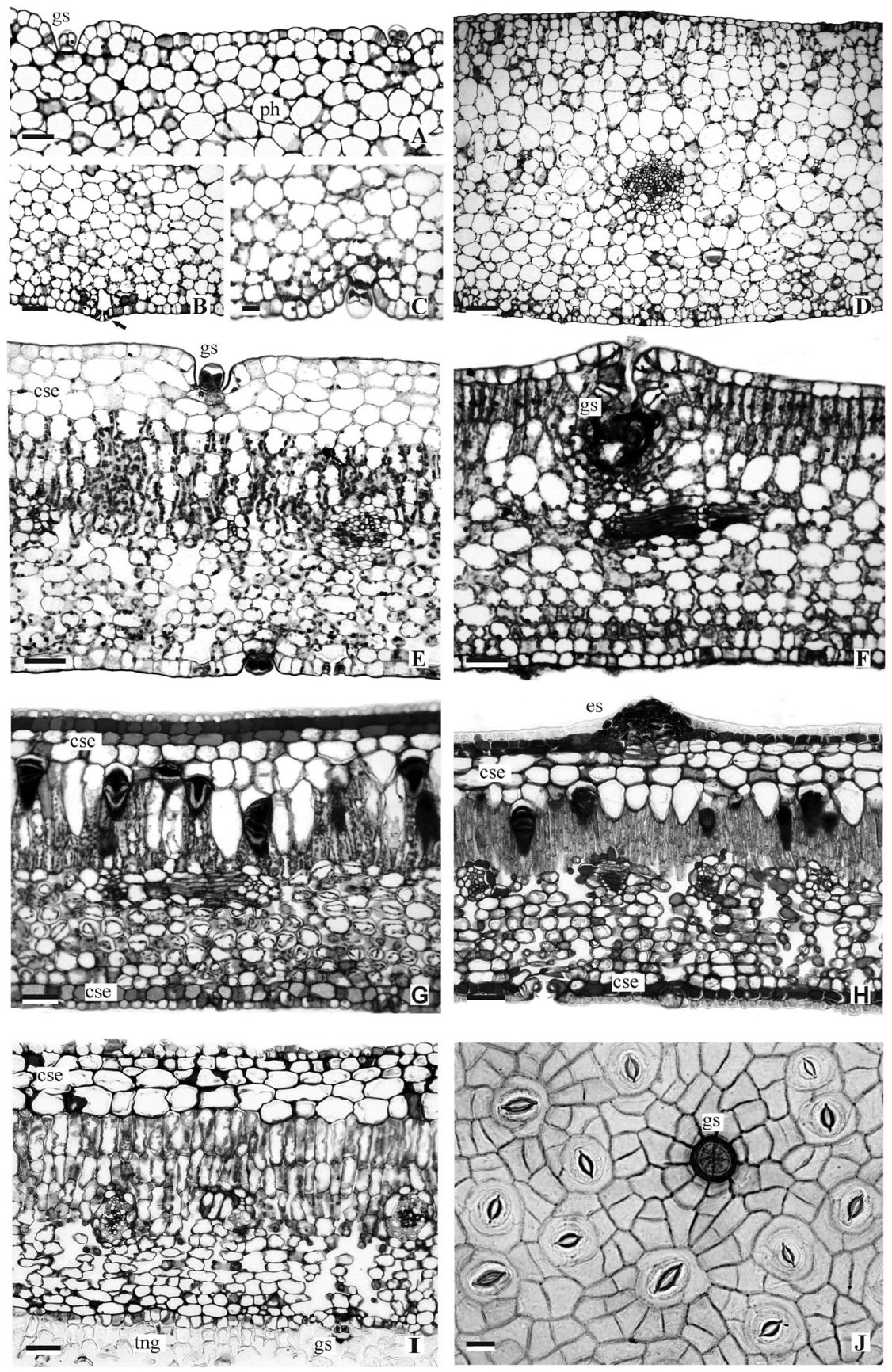

Fig. 1. Transverse sections of leaf blades of A. schaueriana (A, B, C, D and I), L. racemosa (E and F) and $R$. mangle (G and $\mathrm{H}$ ) in Light Microscopy. A-C. Detail of adaxial and abaxial surface of cotyledon, showing stomata (arrow), salt glands (gs) and mesophyll with homogeneous parenchyma (ph). D. Amphistomatic cotyledon with dorsiventral mesophyll. E. Hypostomatic seedling leaf, with salt glands in both epidermal surface and subepidermal layers (cse). F. Seedling leaf with salt glands in adaxial face and dorsiventral mesophyll. G and H. Hypostomatic seedling leaf and sapling leaf, respectively, with subepidermal layers and dorsiventral mesophyll. Detail of suber structure (es). I. Hypostomatic sapling leaf with salt glands, glandular trichomes (tng) and subepidermal layers. J. Paradermic section. Abaxial surface with stomata and salt glands (gs) of A. schaueriana nomophyll. Bars: $100 \mu \mathrm{m}$ (D), $50 \mu \mathrm{m}$ (A, B, E - I), $20 \mu \mathrm{m}$ (C and J). 
the adaxial surface and 15-17 layers of spongy parenchyma below (Fig. 1D).

Seedlings and saplings: In all three species, leaves of seedlings and saplings had a dorsiventral mesophyll (Fig. 1E, Fig. 1F, Fig. $1 \mathrm{G}$, Fig. $1 \mathrm{H}$ and Fig. 1I). The epidermis was uniseriate in all species; composed of rounded cells and straight external periclinal walls covered with a thin cuticle in seedlings and saplings in A. schaueriana (Fig. 1E); in L. racemosa seedlings had rectangular cells (Fig. 1F) while saplings were composed of rounded cells with convex periclinal walls, both covered with a thin cuticle; in $R$. mangle it was composed of rounded cells with external periclinal convex cell walls, covered with a thick cuticle in seedlings and saplings (Fig. $1 \mathrm{G}$, Fig. 1H). Blades were hypostomatic with diacytic stomata in $A$. schaueriana, with salt glands (Fig. 1I, Fig. 1J) present on both surfaces and trichomes only on adaxial surface in seedlings; in saplings both surfaces had glandular trichomes (Fig. 2A), in higher density on the abaxial surface. In $L$. racemosa, blades were amphistomatic (Fig. 2B), with trichomes on the abaxial surface and stomata were anomocytic (Fig. 2C); salt glands occurred in depressions on the adaxial surface (Fig. 2D). R. mangle had hypostomatic blades, with stomata of ciclocytic type; cork structures (Fig. 2E) occurred on both surfaces of the saplings' leaves: in surface view, these structures presented a concentric organization, characterized by a suberization of one or more epidermal cells disposed radially (Fig. 2E, Fig. 2F).

Mesophyll of seedlings and saplings leaves was dorsiventral (Fig. 1D-1I). Below adaxial epidermis, three to four layers of hypodermal cells occurred in seedlings and saplings leaves of A. schaueriana (Fig. 1E). In seedlings, below the adaxial surface occurred four to five layers of palisade parenchyma, and ten to eleven layers of spongy parenchyma, while in saplings ocurred three to five layers of palisade parenchyma and six to eight layers of spongy parenchyma in A. scaheuriana. In L. racemosa, the mesophyll of seedlings leaves had two layers of palisade parenchyma and 9-11 layers of spongy parenchyma (Fig. 1F) while in saplings leaves it had two to three layers of palisade parenchyma and 12-14 layers of spongy cells. $R$. mangle seedlings leaves had four to five layers of hypodermal cells below adaxial surface (Fig. 1G) while saplings leaves had five to seven cells layers of varied shape (Fig. 1H). Two or three layers of cubic cells occurred below the abaxial epidermis in seedlings and saplings. The mesophyll was composed of one to two layers of palisade parenchyma and nine to ten layers of spongy parenchyma. Druses and collateral vascular bundles occurred in the mesophyll of all species. H-shaped sclereids occurred in $R$. mangle (Fig. 2G).

The mean values of the quantitative morphological traits for each species are presented on Table 1. Saplings leaves of all species presented the higher area when compared to other leaf types studied in each species. $R$. mangle presented the highest mean value for this trait (Table 1). Dry mass followed the same pattern, except for $A$. schaueriana cotyledons, which showed equally high dry mass value. The specific leaf area was different for all three species: higher values were observed for seedlings leaves of $A$. schaueriana, cotyledons of $L$. racemosa and saplings leaves of A. schaueriana and $R$. mangle. Density was similar to cotyledons and seedlings leaves in A. schaueriana and $L$. racemosa. In $R$. mangle, seedlings leaves were denser than saplings (Table 1).

The total thickness was higher in the cotyledons of $A$. schaueriana and L. racemosa when compared to other leaf types. The leaves of seedlings and saplings of A. schaueriana and $R$. mangle showed no differences. Seedlings leaves of $A$. schaueriana showed the lowest value among all species while saplings leaves of $L$. racemosa had the highest values. The mean values of palisade parenchyma thickness were higher in saplings leaves of A. schaueriana and L. racemosa, and seedlings leaves of $R$. mangle. This tissue was not present in cotyledons of $A$. schaueriana, composed of a homogeneous parenchyma. The mean values of spongy parenchyma thickness were similar between leaves of seedlings and saplings of 

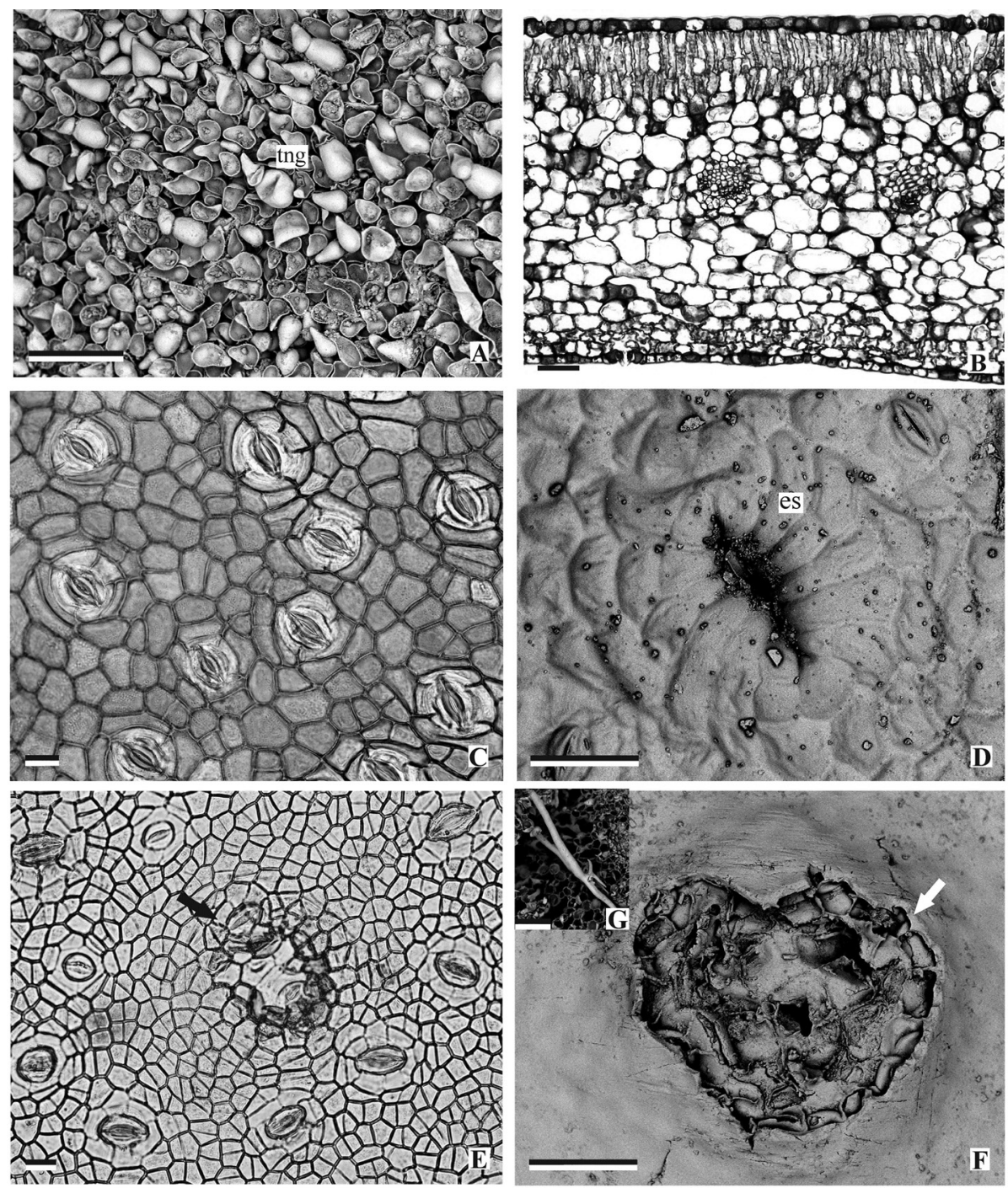

Fig. 2. Epidermis and mesophyll of leaves in Light Microscopy (B, C and E) and Scanning Electron Microscopy (A, D, F and $\mathrm{G}$ ) of A. schaueriana, L. racemosa and R. mangle L. A. Abaxial surface with glandular trichomes (tng) of A. schaueriana sapling leaf. B. Amphistomatic sapling leaf with dorsiventral mesophyll of L. racemosa. C. Adaxial surface with stomata of $L$. racemosa seedling leaf. D. Detail of salt gland and stomata on the adaxial surface of $L$. racemosa seedling leaf. E. Adaxial surface with stomata and suber structure (arrow) of $R$. mangle. F. Detail of suber structure (es) of $R$. mangle. G. Detail of H-shaped sclereids in the mesophyll of $R$. mangle. Bars: $100 \mu \mathrm{m}$ (A and G), $50 \mu \mathrm{m}(\mathrm{B}, \mathrm{D}$ and F), $20 \mu \mathrm{m}(\mathrm{C}$ and $\mathrm{E})$.

all species, except for the cotyledon of L. racemosa, which was higher. The palisade/spongy parenchyma thickness ratio in all species was $<$ 1, except for the saplings leaves of $A$. schaueriana (Table 1).

The Principal Component Analysis (Fig. 3) found that the two first components (PC1 and $\mathrm{PC} 2$ ) explained $85.8 \%$ of the analysed traits total variance. PC1 explained $70.8 \%$ of the variance and is mainly represented by spongy parenchyma thickness. PC2 explained $14.5 \%$ of the variance and is mainly represented by palisade parenchyma thickness (Table 2). In PC1 axis, spongy parenchyma thickness is negatively correlated with leaf dry mass while in PC2 palisade parenchyma thickness is 


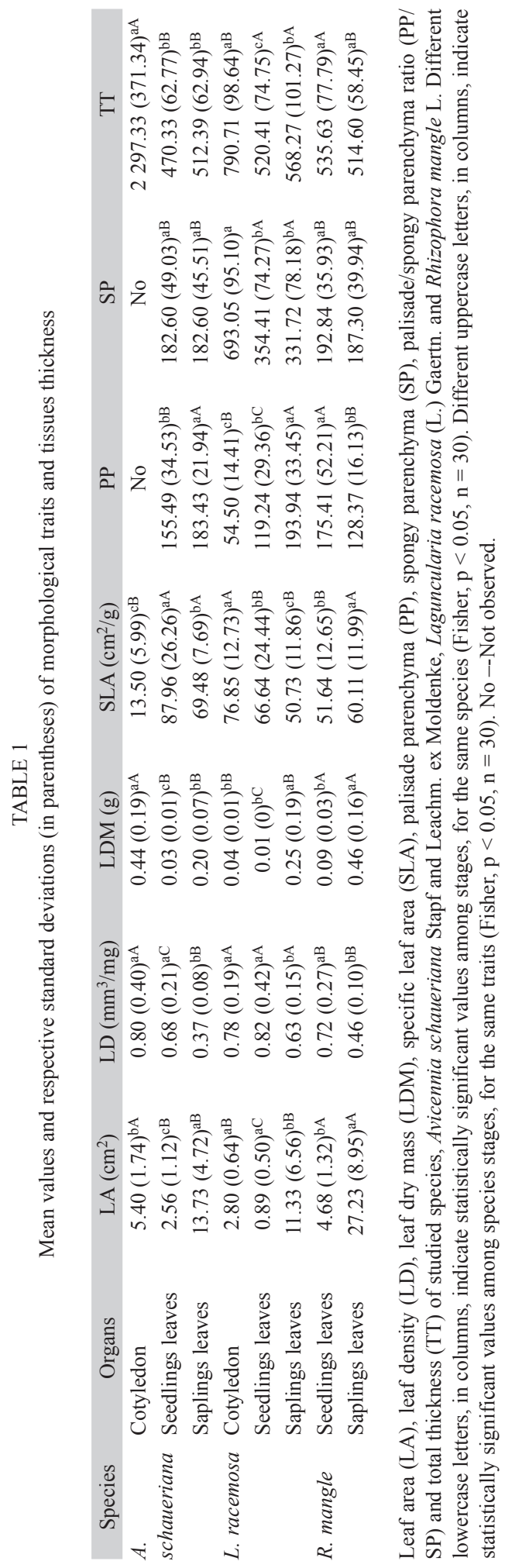

TABLE 2

Correlation matrix of principal components analysis of selected morphological traits of studied species

\begin{tabular}{lcc}
\multicolumn{1}{c}{ Leaf traits } & \multicolumn{2}{c}{ Principal components } \\
& Axis 1 & Axis 2 \\
Spongy parenchyma thickness & 0.99 & 0.012 \\
Palisade parenchyma thickness & 0.021 & 0.9877 \\
Leaf density & 0.23 & -0.22 \\
Leaf dry mass & -0.25 & 0.11 \\
Eigenvalue & 8382.33 & 1775.22 \\
\% Variance & 70.8 & 14.9 \\
\hline
\end{tabular}

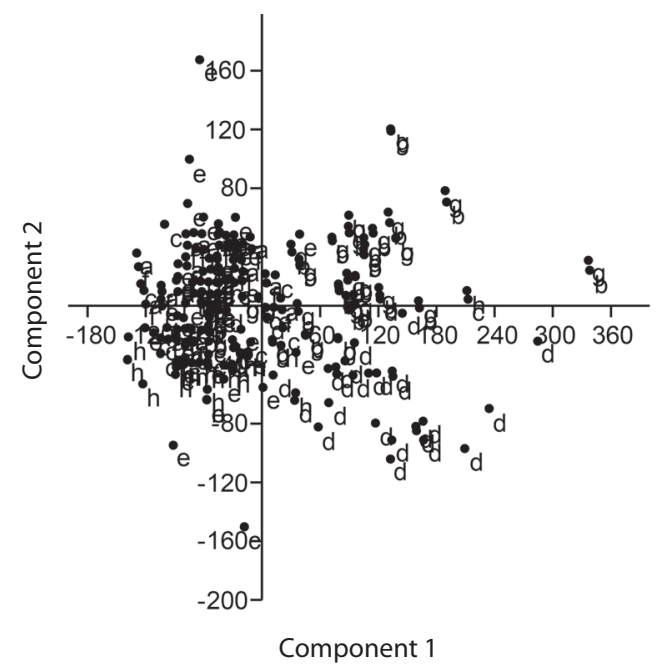

Fig. 3. Principal component analysis of leaf traits (palisade and spongy parenchyma thickness, leaf density and dry mass) of studied species. Legend: a (A. schaueriana cotyledons); b (L. racemosa cotyledons); c (A. schaueriana seedlings leaves); d (L. racemosa (L.) Gaertn. seedlings leaves); e (R. mangle L. seedlings leaves); $\mathrm{f}(A$. schaueriana saplings leaves); g (L. racemosa saplings leaves); h $(R$. mangle saplings leaves).

negatively correlated to leaf density. The PCA also indicated that all leaves of the studied species form one group, except for L. racemosa saplings and seedlings leaves which in PC1 form a diffuse group (Fig. 3).

\section{DISCUSSION}

The studied leaf types presented differences regarding their structure within and among the species. Seedlings and saplings 
leaves had a more complex structural organization when compared to cotyledons. The major differences observed were related to leaf area and dry mass, where the highest values were found in saplings. As they constitute the first true leaves of the plant, long-lived and the main photosynthetic organ, a higher area, and mass are expected (Souza, 2003), especially regarding $R$. mangle that showed the highest values for these traits.

The highest dry mass values of saplings leaves can be related to a higher leaf area when compared to the other leaf types (Turner, 1994). Larger leaf surfaces represent a morphological advantage in shaded environments, such as mangrove understory, because they allow greater light capture (Givnish, 1988; Lambers, Chapim III, \& Pons, 1998). A. schaueriana cotyledons had highest values for dry mass than seedlings and saplings, which can be correlated to high values for total thickness, due to the presence of reserve tissue (Kitajima, 1992). In A. marina (Forsk.) Vierh., cotyledons accumulate nutrients during development supplying growth energy requirements under conditions of high salinity (Bezerra, Lacerda, Filho, de Abreu, \& Prisco, 2007; Wang, Ke, Tam, \& Wong, 2002; Yan, Wang, \& Tang, 2007).

Leaf thickness is considered one of the parameters directly related to variations in specific leaf area (SLA) and leaf density, due to number and size of cellular strata (Vendramini et al., 2002). In general, all leaf types studied can be considered thick when compared to other studies. Halophytes tend to have thick leaves because of the presence of water reserve tissues (Boeger \& Gluzezak, 2006). Besides water reserve tissues, the thickness observed in the mangrove leaf types studied can be explained also by the presence of hypodermal layers in seedlings and saplings leaves of $A$. schaueriana and $R$. mangle, a thick spongy parenchyma in cotyledons, seedlings and saplings leaves of $L$. racemosa, and several layers of homogeneous parenchyma in A. schaueriana cotyledons. Salinity may induce an increase in leaf succulence for water conservation (Borkar, Athalye, \& Goldin, 2011; Sobrado, 2007) allowing a better salt dissolution among the water storage tissues (Sobrado, 2007).

The presence of hypodermal layers can be considered a conspicuous xeromorphic feature of mangrove leaves, functioning as an additional barrier between epidermis and photosynthetic tissues, water storage, accumulation of salt or osmotic regulation (Feller, 1996; Saenger, 2002). Studies indicate that the hypodermis in $R$. mangle plays a role in sequestration and storage of $\mathrm{Na}$ and $\mathrm{Cl}$, controlling ions concentration of the photosynthetic tissues (Werner \& Stelzer, 1990).

In this study, the specific leaf area varied considerably among species and leaf types. The highest values observed can be associated to the occurrence of water storage tissues (Meziani \& Shipley, 1999). Among all morphological features investigated until now, the authors agree that the specific leaf area is regarded as a main indicator trait of growth rate and resource use strategy (Evans \& Poorter, 2001). A. schaueriana seedlings drift away once released from the mother tree, so a higher specific leaf type area (SLA) improves its establishment potential once anchored. L. racemosa invests more in early stages, then the seedling has the highest SLA value. $R$. mangle invests more in the sapling as the species spends its earliest stages of growth attached to the mother tree.

The leaf types studied presented different patterns of stomata distribution. The hypostomatic type observed in cotyledons, leaves of seedlings and saplings of $A$. schaueriana and leaves of seedlings and saplings of $R$. mangle are the most common patterns among eudicots (Dickson, 2000; Pyykkö, 1979).

On the other hand, the amphistomatic type observed in leaves of L. racemosa are considered common in xeric (Fahn \& Cutler, 1992) and also in thick leaves $(>0.5 \mathrm{~mm}$ ) (Boeger et al., 2006; Boeger, Cavichiolo, Pil, \& Labiak, 2007). Leaf thickness imposes a limitation on the inner diffusion of gases due to the greater distance through the mesophyll. The occurrence of stomata on both leaf surfaces optimizes leaf conductance of gases (Mott, Gibson, \& O'Leary, 1982; Thompson, Kriedemann, \& 
Craig, 1992). Although A. schaueriana and $R$. mangle leaves are also considered thick, the presence of subepidermal well developed layers on the adaxial surface of seedlings and saplings leaves of these species seems to favor the hypostomatic type (Arruda, Viglio, \& Barros, 2009).

The dorsiventral mesophyll was the most common type among studied leaves, occurring in all studied species, except for A. schaueriana cotyledons. Interestingly, L. racemosa cotyledons have a dorsiventral mesophyll. The species is considered a pioneer species (Menezes, Shaeffer-Novelli, Poffo, \& Eysink, 2005; Tomlinson, 1995), therefore the presence of a dorsiventral mesophyll in early stages of development, leading to a better light capture by the leaf blade. This is evidenced by the palisade/spongy ratio $<1$, where the mesophyll presented a greater number of spongy parenchyma layers over the palisade tissue. The ratio $<1$ was found in all species and leaf types, which increases the distribution and efficient use of diffuse light within the leaf (Vogelmann, Nishio, \& Smith, 1996), more adapted to shaded environments such as mangrove understory. L. racemosa has a much thicker spongy parenchyma in all leaf stages, when compared to co-ocurring species. Although considered a shade intolerant species (Twilley \& Day Jr, 2013), studies show that it can be shade tolerant in early stages of growth. A. schaueriana cotyledons showed a homogeneous mesophyll, which is characteristic of the genus Avicennia, also observed in A. marina (Bezerra et al., 2007; Yan et al., 2007), typical of reserve cotyledons, in general.

In mangrove ecosystems, influenced directly by salinity, the presence of salt glands is a key adaptation to keep the osmotic balance of the plant body, contributing to the compartmentalization and elimination of salt excess, regulating salt concentration in the leaves, and allowing the species to tolerate different salinity gradients (Fahn \& Cutler, 1992; Lin, 1984). Salt glands were observed in all L. racemosa and $A$. schaueriana leaf types, except in $L$. racemosa cotyledons. The analysis of the leaf surface of these species revealed variations in the position and density of salt glands.

The highest salt gland density was observed in A. schaueriana. Gland density may vary according to the salinity (Borkar et al., 2011). Studies with $A$. marina showed that the salt gland density varied inversely with salinity and leaf age (Drennan \& Berjak, 1982; Naidoo, 2010). In L. racemosa, salt glands occurred only on the adaxial surface of seedlings and saplings leaves, with similar densities. Variations in the density of salt secretory structures among species seem to be influenced by tolerance of each species to salinity and several other elimination mechanisms adopted by these species (Tomlinson, 1995; Parida \& Jha, 2010).

The studied species showed several traits directly related to water loss prevention such as the presence of thick cuticle and hypodermis, besides the occurrence of salt glands and mechanisms for salt exclusion. Also, the presence of tissues for water storage is another strategy to save water and help maintaining ions balance. The morphological attributes showed a considerable variation among leaf types and species, highlighting the different strategies of leaves at various stages of development to survive and overcome the many abiotic factors they are subject to in a dynamic ecosystem such as mangroves. As stated by Ungar (1982), in halophytes, the early stages of development are the most sensitive in species life cycle. Small and thick leaves and reduced leaf area are also features that can be correlated to the restrictive conditions of mangroves (Sobrado, 2001; Naidoo, 2006).

There are fundamental differences between mangrove species in terms of water and nutrient use under stress, which reflects plant structure. $R$. mangle is the most tolerant to high salinity levels (Krauss \& Allen, 2003), common in the fringe of mangroves, able to cope with freshwater and sea water (Smithsonian Marine Station at Ft Pierce, 2001). Physiologically, it is a salt excluder, with a mechanism of salt ultrafiltration in cell membranes of roots (Tomlinson, 1995). Here the species stands out with the most xeromorphic features. Some authors 
(López-Hoffman, Ackerly, Anten, Denoyer, \& Martinez-Ramos, 2007) demonstrated that $R$. mangle seedlings can grow in all light levels, but saplings depend on high light levels in order to grow. That would explain the presence of a well-developed hypodermis and thick cuticle, strategies that enhance growth in more exposed areas, also helping in water loss control in high salinity levels. On the other hand, Kathiresan and Rajendran (2002) in the study of $R$. apiculata seedlings showed that in higher light intensity plants have a lower growth.

$L$. racemosa grows under a variable range of salinities (Lovellock \& Feller, 2003; Sobrado, 2004), affected by hyper-saline environments (Lovellock \& Feller, 2003; Sobrado, 2005). Seedlings and adults are less tolerant to high salinity and changes in water level than $R$. mangle (Cardona-Olarte et al., 2006). The species is a salt secreting species, occurring in the medium to high intertidal areas in mangroves (Tomlinson, 1995). Although considered a pioneer species (Tomlinson, 1995; Bigarella, 2001), L. racemosa establishes in open sites with low salinity and high nutrients levels, presenting a high mortality of seedlings (Tomlinson, 1995). Accordingly to some authors (Sereneski-de Lima, Boeger, Larcher-de-Carvalho, Pelozzo, \& Soffiatti, 2013), it is the most sclerophyllous species compared to the other two. Regarding anatomy and morphology, $L$. racemosa presents the highest density values for all leaf types, and the thickest sapling leaf, which can be considered a response to salinity (Cram, Torr, \& Rose, 2002).

Avicennia is a salt excluder, salt secreting and salt accumulator species (Parida \& Jha, 2010). Studies with A. marina showed that the species is highly tolerant to high salinity levels and a water conservation specialist, due to the presence of trichomes covering leaf surfaces (Lovelock and Feller, 2003). López-Hoffman et al. (2007) observed for $A$. germinans that its establishment was shade-promoted. Thus low and medium light levels are better for seedlings populations' growth. The species shows a dorsiventral mesophyll with similarly thick palisade and spongy parenchyma, in both seedlings and saplings leaves. Considering all studied traits, A. schauerianna showed traits values more similar to $R$. mangle than $L$. racemosa, as demonstrated by the PCA analysis where the latter traits appear more separated than the other two.

\section{ACKNOWLEDGMENTS}

This paper is part of a Master Thesis supervised by M. R. T. Boeger at the Universidade Federal do Paraná, Curitiba, Brazil. We thank Araucaria Fundation and Petrobrás for financial support; the Federal Universities Brazilian Project (REUNI) for scholarship to the first author; to the Brazilian Research Council (CNPq) for providing the fellowship to MRT Boeger (Process nº. 309386/2007-1).

\section{RESUMEN}

La fase inicial del ciclo de vida de una planta es un período corto y crítico, cuando los individuos son más vulnerables a factores ambientales. El estudio morfológico y anatómico del tipo de hojas de las plántulas y árboles pequeños, permite la comprensión de las estrategias de las especies, que es de importancia fundamental para su establecimiento y supervivencia. El objetivo de este estudio fue analizar la estructura de los tipos de hojas de las plántulas y árboles pequeños de tres especies de mangle: Avicennia schaueriana, Laguncularia racemosa y Rhizophora mangle, para entender sus estrategias de vida tempranas de adaptación al ambiente. Un total de 30 cotiledones completamente abiertos (A. schaueriana y L. racemosa), 30 hojas de plántulas, y 30 hojas de árboles pequeños de cada especie se recolectaron en una área de manglar en Bahía Guaratuba, Estado de Paraná, Brasil. Siguiendo los métodos estándares, se prepararon muestras para análisis morfológicos (biomasa de hoja seca, densidad y espesor) y anatómicos (epidermis y capas sub-epidérmicas, tipos de estomas, densidad de glándulas secretoras de sal y grosor del parénquima empalizado y del esponjoso). Para comparar los tipos de hojas entre las especies se utilizaron un modelo lineal y Análisis de Componentes Principales, mientras que un análisis de conglomerados evaluó las diferencias entre las especies. Observamos diferencias estructurales significativas entre tipos de hoja en las especies. A. schaueriana mostró cotiledones más gruesos, mientras que $L$. racemosa presenta una estructura dorsiventral. Se observaron valores más altos del área foliar específica para las hojas de las plántulas de A. schaueriana, cotiledones de L. racemosa y hojas de árboles pequeños de $A$. schaueriana y $R$. mangle. La densidad de la hoja fue similar a la de los 
cotiledones y hojas de plántulas de $A$. schaueriana y $L$. racemosa, mientras que $R$. mangle tenía las hojas de las plántulas más gruesas que los árboles pequeños. A. schaueriana y $R$. mangle mostraron hojas hipostomáticas; L. racemosa anfiestomáticas; por otro lado A. chaueriana mostró estomas diacíticos, L. racemosa anomocíticos y $R$. mangle ciclocíticos. Las hojas de las plántulas eran más gruesas en $R$. mangle (535 micras) y L. racemosa (520 micras) que en $A$. schaueriana $(470.3 \mathrm{~m})$; mientras que las hojas de las plántulas eran más gruesas en L. racemosa $(568.3 \mathrm{~m})$ que en $A$. schaueriana (512.4 micras) y $R$. mangle (514.6 $\mathrm{m})$. Además el parénquima empalizado de las plántulas mostró un aumento de espesor en L. racemosa $(119.2 \mathrm{~m})<$ A. schaueriana $(155.5 \mathrm{~m})<R$. mangle $(175.4 \mathrm{~m})$; mientras que en las hojas de los árboles pequeños fue de siguiente manera: $R$. mangle $(128.4 \mathrm{~m})<$ A. schaueriana $(183.4 \mathrm{~m})$ $<$ L. racemosa $(193.9 \mathrm{~m})$. Del mismo modo, en las hojas de las plántulas los valores del espesor del parénquima esponjoso fueron: A. schaueriana $(182.6 \mathrm{~m})=R$. mangle $(192.8$ $\mathrm{m})<$ L. racemosa $(354.4 \mathrm{~m})$; mientras que en los árboles pequeños: A. schaueriana $(182.6 \mathrm{~m})=R$. mangle $(187.3$ $\mathrm{m})<$ L. racemosa $(331.3 \mathrm{~m})$. Los rasgos analizados, en diferentes combinaciones, representan ajustes morfológicos de tipos de hojas para reducir la pérdida de agua, eliminar el exceso de sal, aumentar la absorción de la luz, lo que permite una mayor eficiencia en el mantenimiento de los procesos fisiológicos en esta etapa de crecimiento inicial.

Palabras clave: estrategias de adaptación, cotiledones, morfología funcional, adaptaciones morfológicas, glándulas de sal.

\section{REFERENCES}

Arruda, R. C. O., Viglio, N. S. F., \& Barros, A. A. M. (2009). Anatomia foliar de halófitas e psamófilas reptantes ocorrentes na restinga de Ipitangas, Saquarema, Rio de Janeiro, Brasil. Rodriguésia, 60, 333-352.

Bezerra, M. A., de Lacerda, C. F., Filho., E. G., de Abreu., C. E. B., \& Prisco, J. T. (2007). Physiology of cashew plants grown under adverse conditions. Brazilian Journal of Plant Physiology, 19, 449-461.

Bigarella, J. J. (2001). Contribuição ao estudo da planície litorânea do estado do Paraná. Brazilian Archives of Biology and Technology an International Journal, Jubilee Volume 1946-2001, 65-110.

Boeger, M. R. T., Cavichiolo. L. E., Pil., M. W., \& Labiak, P. H. (2007). Variabilidade fenotípica de Rumohra adiantiformis (G. Forst) Ching (Dryopteridaceae). Hoehnea, 34, 553-561.

Boeger, M. R. T., \& Gluzezak, R. M. (2006). Adaptações estruturais de sete espécies de plantas para as condições ambientais da área de dunas de Santa Catarina, Brasil. Iheringia, 61, 73-82.
Boeger, M. R. T., Kaehler, M., Melo Jr, J. C. F., Gomes, M. Z., Oliveira. L. da S., Chaves, C. R. M., \& Schottz, E. de S. (2006). Estrutura foliar de seis espécies do subosque de um remanescente de Floresta Ombrófila Mista. Hoehnea, 33, 521-531.

Borkar, M. U., Athalye, R. P., \& Goldin, Q. (2011). Salinity induced changes in the leaf anatomy of the mangrove Avicennia marina along the anthropogenically stressed tropical creek. Journal of Coastal Development, 14, 191-201.

Cardona-Olarte, P., Twilley, R. R., Krausse, K. W., \& Rivera-Monroy, V. (2006). Responses of neotropical mangrove species grown in monoculture and mixed culture under treatments of hydroperiod and salinity. Hydrobiologia, 569, 325-341.

Cintrón, G., \& Schaeffer-Novelli, Y. (1984). Methods for studying mangrove structure. In S. C. Snedaker \& J. G. Snedaker (Eds.), The Mangrove Ecosystem: Research Methods. USA: UNESCO.

Cram, W. J., Torr, P. G., \& Rose, D. A. (2002). Salt allocation during leaf development and leaf fall in mangroves. Trees, 16, 112-119.

Dickson, W. C. (2000). Integrative Plant Anatomy. San Diego: Harcourt Academic Press.

Drennan, P. M., \& Berjak, P. (1982). Degeneration of the salt glands accompanying foliar maturation in Avicennia marina (Forsskal) Vierh. New Phytologist, 90, 165-176.

Embrapa. (1999). Sistema Brasileiro de Classificação de Solos. Brasília: Embrapa.

Evans, J. R., \& Poorter, H. (2001). Photosynthetic acclimation of plants to growth irradiance: the relative importance of specific leaf area and nitrogen partitioning in maximizing carbon gain. Plant Cell and Environment, 24, 755-767.

Fahn, A., \& Cutler, D. I. (1992). Xerophytes. Berlin: Gebrüder Borntraeger.

Feller, I. C. (1996). Effects of nutrient enrichment on leaf anatomy of dwarf Rhizophora mangle L. (red mangrove). Biotropica, 28, 13-22.

Franklin, G. L. (1945). Preparation of thin sections of synthetic resins and wood-resin composites and a new macerating method for wood. Nature, 155, 24-51.

Givnish, T. J. (1988). Adaptation to sun and shade: a whole-plant perspective. Australian Journal of Plant Physiology, 15, 63-92.

Grubb, P. J. (1977). Control of forest growth and distribution on wet tropical mountains: with special reference to plant nutrition. Annual Review of Ecology and Systematics, 8, 83-107.

Johansen, D. A. (1940). Plant microtecnique. New York: McGraw Hill. 
Kathiresan, K. (2008) Biodiversity in Mangrove ecosystems in India: status, challenges and strategies. In P. Natarajan, K. V. Jayachandran, S. Kannaiyan, B. Ambat, \& A. Augustine (Eds.), Glimpses of Aquatic Biodiversity. Cochin, India: CUSAT.

Kathiresan, K., \& Rajendran, N. (2002). Growth of a mangrove (Rhizophora apiculata) seedlings as influenced by $\mathrm{GA}_{3}$, light and salinity. Revista de Biología Tropical, 50, 525-530.

Kitajima, K. (1992). Relationship between photosynthesis and thickness of cotyledons for tropical tree species. Functional Ecology, 6, 582-589.

Köeppen, W. (1948). Climatologia: con um estúdio de los climas de la Tierra. Mexico: Fondo de Cultura Economica.

Krauss, K. W., \& Allen, J. A. (2003). Influences of salinity and shade on seedling photosynthesis and growth of two mangrove species, Rhizophora mangle and Bruguiera sexangula, introduced to Hawaii. Aquatic Botany, 77, 311-324.

Lambers, H., Chapim III, F. S., \& Pons, T. L. (1998). Plant Physiological Ecology. New York: Springer.

Lin, P. (1984). Mangrove Vegetation. Beijing: China Ocean Press.

López-Hoffman, L., Ackerly, D. D., Anten, N. P. R., Denoyer., J. L., \& Martinez-Ramos, M. (2007). Gapdependence in mangrove life-history strategies: a consideration of the entire life cycle and patch dynamics. Journal of Ecology, 95, 1222-1233.

Lovelock, C. E., \& Feller, I. C. (2003). Photosynthetic performance and resource utilization of two mangrove species coexisting in a hypersaline scrub forest. Oecologia, 134, 455-462.

Menezes, G. V., Shaeffer-Novelli, Y., Poffo, I. R. F., \& Eysink, G. G. J. (2005). Mangrove recovering: a case study at Baixada Santista of São Paulo. Brazil. Brazilian Journal of Aquatic Science and Technology, 9, 67-74

Meziani, D., \& Shipley, B. (1999). Interacting determinants of specific leaf area in 22 herbaceous species: effects of irradiance and nutrient availability. Plant, Cell and Environment, 22, 447-459.

Mott, K. A., Gibson, A. C., \& O’Leary, J. E. (1982). The adaptative significance of amphistomatic leaves. Plant Cell and Environment, 5, 455-460.

Naidoo, G. (2006). Factors contributing to dwarfing in the mangrove Avicennia marina. Annals of Botany, 97, 1095-1101.

Naidoo, G. (2010). Ecophysiological differences between fringe and dwarf Avicennia marina mangroves. Trees, 24, 667-673.

Noernberg, M. A., Angelotti, R., Caldeira, G. A., \& Ribeiro de Sousa, A. F. (2008). Determinação da sensibilidade do litoral paranaense à contaminação por óleo. Brazilian Journal of Aquatic Science and Technology, 12, 49-59.

Paraguassu, L. A. A., \& Silva, N. M. (2007). Caracterização fitossociológica do manguezal de Porto de Sauípe, Entre Rios, Bahia. Diálogos e CiênciaRevista da Rede de Ensin, 12, 1-11.

Parida, A. K., \& Jha, B. (2010). Salt tolerance mechanisms in mangroves: A review. Trees, 24, 199-217.

Patel, N. T., Gupta, A., \& Pandey, A. N. (2010). Salinity tolerance of Avicennia marina (Forssk.) Vierh. from Gujarat coasts of India. Aquatic Botany, 93, 9-16.

Pyykkö, M. (1979). Morphology and anatomy of leaves from some woody plants in a humid tropical forest of Venezuelan Guayana. Acta Botanica Fennica, $112,1-41$.

Ressel, K., Guilherme, F. A. G., Schiavini, I., \& Oliveira, P. E. (2004). Ecologia morfofuncional de plântulas de espécies arbóreas da Estação Ecológica do Panga, Uberlândia, Minas Gerais. Revista Brasileira de Botânic, 27, 311-323.

Saenger, P. (2002). Mangrove ecology, silviculture and conservation. The Netherlands: Kluwer Academic Publishers.

Schaeffer-Novelli, Y., Cintrón-Molero, G., \& Adaime, R. R. (1990). Variability of mangrove ecosystemsalong the Brazilian coast. Estuaries, 13, 204-218.

Schaeffer-Novelli, Y., Cintrón-Molero, G., Soares, M. L. G., \& De-Rosa, T. (2000). Brazilian mangroves. Aquatic Ecosystem Health and Management, 3, 561-570.

Sereneski-de Lima, C., Boeger, M. R. T., Larcher-deCarvalho, L., Pelozzo, A., \& Soffiatti, P. (2013). Sclerophylly in mangrove tree species from South Brazil. Revista Mexicana de Biodiversidad, 84, 1159-1166.

Silva, J. M., Martins, M. B. G., \& Cavalheiro, A. J. (2010). Caracterização anatômica e perfis químicos de folhas de Avicennia schaueriana Stapf. and Leech. ex Moldenke e Rhizophora mangle L. de manguezais impactados e não impactados do litoral paulista. Insula, 39, 14-33.

Smithsonian Marine Station at Ft Pierce (SMSF). (2001). Rhizophora mangle. Retrieved from http://www.sms. si.edu/irlspec/Rhizop mangle.htm .

Sobrado, M. A. (2001). Hydraulic properties of a mangrove Avicennia germinans as affected by $\mathrm{NaCl}$. Biologia Plantarum, 44, 435-438.

Sobrado, M. A. (2004). Influence of external salinity on the osmolality of xylem sap, leaf tissue and leaf gland secretion of the mangrove Laguncularia racemosa (L.) Gaertn. Trees, 18, 422-427. 
Sobrado, M. A. (2005). Leaf characteristics and gas exchange of the mangrove Laguncularia racemosa as affected by salinity. Photosynthetica, 43, 217-221.

Sobrado, M. A. (2007). Relationship of water transport to anatomical features in the mangrove Laguncularia racemosa grown under contrasting salinities. New Phytologist, 173, 584-591.

Souza, L. A. (2003). Morfologia e anatomia vegetal (célula. tecidos. órgãos e plântula). Ponta Grossa: Editora da Universidade Estadual de Ponta Grossa.

STATISTICA (data analysis software system) (version 7.0) [Computer program]. Oklahoma: StatSoft, Inc.

Thompson, W. A., Kriedemann, P. E., \& Craig, I. E. (1992). Photosynthetic response to light and nutrients in suntolerant and shade-tolerant rainforest trees. I. Growth, leaf anatomy and nutrient content. Australian Journal of Plant Physiology, 19, 1-18.

Tomlinson, P. B. (1995). The botany of mangroves. Cambridge: Cambridge University Press.

Turner, I. M. (1994). Sclerophylly: primarily protective? Ecology, 8, 669-675.

Twilley, R. R., \& Day Jr, J. W. (2013). Mangrove wetlands. In J. W. Day Jr., B. C. Crump, W. M. Kemp, \& A. Yáñez-Arancibia (Eds.), Estuarine Ecology (pp. 165202). Singapore: Wiley-Blackwell.

Ungar, I. A. (1982). Germination ecology of halophytes. In D. N. Sen, \& K. Rajpurohit (Eds.), Contributions to the Ecology of Halophytes. Tasks for vegetation science (pp. 143-154). The Hague: Springer.
Vendramini, F., Díaz, S., Gurvich, D. E., Wilson, P. J., Thompson, K., \& Hodgson, J. G. (2002). Leaf traits as indicators of resource use strategy in floras with succulent species. New Phytologist, 154, 147-157.

Vogel, E. F. (1980). Seedlings of dicotyledons: structure, development types: descriptions of 150 woody Malesian taxa. Wageningen: Centre for Publishing and Documentation.

Vogelmann, T. C., Nishio, J. N., \& Smith, W. K. (1996). Leaves and light capture: light propagation and gradients of carbon fixation within leaves. Trends in Plant Science, 1, 65-70.

Wang, W. Q., Ke, L., Tam, N., \& Wong, Y. S. (2002). Changes in the main osmotica during the development of Kandelia candel hypocotyls and after mature hypocotyls were transplanted in solutions with different salinities. Marine Biology, 141, 1029-1034.

Werner, A., \& Stelzer, R. (1990). Physiological responses of the mangrove Rhizophora mangle grown in the absence and presence of $\mathrm{NaCl}$. Plant Cell and Environment, 13, 243-255.

Witkowski, E. T. F., \& Lamont, B. B. (1991). Leaf specific mass confounds leaf density and thickness. Oecologia, 88, 486-493.

Yan, Z., Wang, W., \& Tang, D. (2007). Effect of different time of salt stress on growth and some physiological processes of Avicennia marina seedlings. Marine Biology, 152, 581-587. 
